\title{
Non-invasive hair sampling of Neotropical otters
}

\author{
Nuno M. Pedroso ${ }^{1,2 *}$, Sofia V. Dias ${ }^{2}$, Thais Rovere Diniz-Reis ${ }^{1}$, Margarida Santos-Reis ${ }^{2} \&$ \\ Luciano Martins Verdade \\ ${ }^{1}$ Universidade de São Paulo, Centro de Energia Nuclear na Agricultura, Caixa Postal 96, Piracicaba, \\ 13416-000, Piracicaba, SP, Brasil. \\ ${ }^{2}$ Universidade de Lisboa, Faculdade de Ciências, Centro de Ecologia, Evolução e Alterações Ambientais, \\ Ed. C2, Campo Grande, 1749-016, Lisboa, Portugal. \\ *Corresponding author: Nuno M. Pedroso,e-mail: nmpedroso@fc.ul.pt
}

PEDROSO, N. M., DIAS, S. V., DINIZ-REIS, T. R., SANTOS-REIS, M., VERDADE, L. M. Non-invasive

hair sampling of neotropical otters. Biota Neotropica. 18(4): e20180579. http://dx.doi.org/10.1590/1676-

0611-BN-2018-0579

\begin{abstract}
Sampling wild animal populations using non-invasive techniques is advised when dealing with threatened species. Hair samples provide ecological information like species and individual identification. However, hair trapping is scarcely used in otters, due to their aquatic habits. Most studies are with captive individuals, so there is the need to test non-invasive hair trapping methods in otters in the wild. The aim of this study was to develop a simple and cost-effective method to collect hair from otter species in a non-invasive way. The study was carried out in the Paranapanema River, São Paulo State, Brazil, with the Neotropical otter (Lontra longicaudis Olfers, 1818), a protected species. Hair traps (wooden sticks and tree roots with adhesive tape or wax bands) were set during six nights on river banks, otter trails and scent-marking sites. Traps were baited with otter fresh spraints from other river locations. From the 23 traps, 10 (43.7\%) were successful in collecting otter hairs, mostly guard-hair. The sticks were much more efficient than the roots at capturing otter hair (70.6.\% vs. $0 \%)$ as well as adhesive tape when compared to wax (71.4\% vs. $0 \%$ ). Method simplicity and efficiency suggest that it can be a cost-effective way for collecting otter hairs without the need for capturing individuals. This method can be used for: assessment of local otter distribution; collecting otter hair samples for sex and individual identification (by molecular analysis), trophic ecology (by isotopic analyses), ecotoxicology (by contamination analysis) or behaviour ecology (by hormonal and stress levels analysis). More trapping campaigns should be implemented to further test the method's efficiency. Keywords: hair trap, Lontra longicaudis, non-invasive methods, Brazil.
\end{abstract}

\section{Coleta não invasiva de pelos de lontra Neotropical}

Resumo: O uso de técnicas de amostragem não-invasivas é aconselhado quando se trabalha com espécies ameaçadas de animais selvagens. Amostras de pelo fornecem informações ecológicas, como a identificação ao nível da espécie e do indivíduo. No entanto, a coleta de pelo é pouco usada em lontras, devido aos seus hábitos aquáticos. A maioria dos estudos é feita com indivíduos em cativeiro, existindo por isso a necessidade de testar métodos não invasivos de coleta de pelos de lontras na natureza. O objetivo deste estudo foi desenvolver um método simples e com uma boa relação custo-benefício para coletar pelos de espécies de lontra de maneira não invasiva. O estudo foi realizado no rio Paranapanema, Estado de São Paulo, Brasil, com a lontra Neotropical (Lontra longicaudis Olfers, 1818), uma espécie protegida. Armadilhas de pelo (estacas de madeira e raízes de árvores com fita adesiva ou bandas de cera depilatória) foram colocadas durante seis noites nas margens do rio, em trilhas e locais de marcação de lontra. As armadilhas foram iscadas com dejetos frescos de lontra de outros locais do rio. Das 23 armadilhas, 10 (43.7\%) foram eficazes na coleta de pelos de lontra, maioritariamente pelos-guarda. As estacas foram muito mais eficientes que as raízes na captura de pelos de lontra (70.6.\% vs. $0 \%)$ tal como a fita adesiva quando comparada com a cera $(71,4 \%$ vs. $0 \%)$. A simplicidade e a eficiência do método sugerem que esta pode ser uma maneira econômica de coletar pelo de lontra sem a necessidade de capturar indivíduos. Este método pode ser usado para: levantamento da distribuição local da lontra; coleta de amostras de pelo de lontra para identificação sexual e individual (por meio de análise molecular); ecologia trófica (por meio de análise isotópica); ecotoxicologia (por meio de análise de contaminantes); e ecologia comportamental (por meio da determinação de níveis hormonais reprodutivos e ligados ao estresse). Mais campanhas de armadilhagem devem ser implementadas para melhor avaliar a eficiência do método.

Palavras-chave: armadilha de pelo, Lontra longicaudis, métodos não-invasivos, Brasil. 


\section{Introduction}

Monitoring or sampling wild animal populations is important to increase our scientific knowledge on the structure and functioning of ecosystems and to inform managers and decision-makers, particularly when dealing with elusive and low density species, still lacking relevant ecological information. At the same time, there is an increasing pressure from the public, environmental and scientific bodies to use non-invasive techniques, in particular when surveying mammals (Sikes \& Gannon 2011).

Among the non-invasive sampling methods that have been developed to survey mammals, hair samples have the advantage of providing ecological information, like species and individual identification (e.g. Foran et al. 1997), hormonal and stress levels (Koren et al. 2002, Macbeth et al. 2010), diet reconstruction based on carbon and nitrogen isotope values (e.g. Hobson et al. 2000, Mitani et al. 2009, Walter et al. 2014) and exposure to environmental contamination (e.g. Pereira et al. 2006). Hair traps are commonly used to sample hairs from wild free-moving animals (e.g. Baker 1980, Mowat \& Strobeck 2000, Vine et al. 2009, Monterroso et al. 2014) as they do not require checking on a daily basis such as snares and leg-hold, Hancock or box traps. However, hair trapping in semi-aquatic mammals is scarcely used due to their aquatic habits while active that difficult its implementation.

Otters are semi-aquatic mammals, most of them elusive and shy species, that rest on land but use water in most of its daily activities and most of the times their dens are on the water edges opening directly to water (Kruuk 2006). Traditional capture methods, such as box/ cage traps, tend therefore to have low capture success (Kranz 1995). Although there are some studies addressing the practicability of various field techniques for capturing and radio-tracking otters (e.g. Ó Néill et al. 2008), modified body-snares or foot-hold traps (Ben-David et al. 1998, Newsome et al. 2009) or Hancock traps (Mitchell-Jones et al. 1984) are not advised due to safety concerns (e.g. sensitivity to stress) especially since all but one (North American river otter - Lontra canadensis Schreber, 1777) out of the thirteen existing otter species in the world have a conservation status of Endangered (EN), Vulnerable (VU) or Near Threatened (NT) and decreasing population trends in most of their range (IUCN 2017). Nevertheless, most of otter species still lack information in some critical parameters, such as population size and structure, occupancy patterns, or genetic diversity. Therefore, non-invasive methods that supply biological samples such as hair trapping should be pursued.

There are still very few published studies on otter hair trapping methods and most of them with captive individuals. To obtain DNAbased population estimates of river otter, Depue \& Ben-David (2007) developed and tested, first in captivity and then in the wild, three traps to capture otter hairs: 1. modified body-snare, 2. modified foot-hold trap, and 3. bucket trap. The first two provided an effective technique for obtaining hair from individual river otters, with a success rate of $94 \%$ and 3-20 guard hairs per capture. Another study, directed to the test methods for estimating the number and recording the distribution of river otter (Johnson et al. 2013), used wire body snares and knaplock hair snag to collect otter hairs for genotyping with the first being more effective than the second. Their data suggested that hair collection was an efficient and cost-effective technique for monitoring the abundance of river otter with known latrine sites. In regard to both studies, and although they did not restrained animals in any trap type, one might argue that breakaway body-snares still causes some type of stressful otter interaction with the trap.

Two other studies were conducted with captive Eurasian otters (Lutra lutra Linnaeus, 1758). Anderson et al. (2006) developed a successful hair trapping method with two clay pipes with Velcro straps with cylindrical geometry placed following initial trails. The success rate of the trap was 0.71 hair samples collected per trap night (five nights out of seven) and hair was successfully used for DNA extraction; however, otters only approached the traps after these were baited with chicks. The other study was conducted by Kuhn (2010) who tested two designs of hair traps (a wooden box and sticks stuck into the soil), two distinct materials (a double-sided adhesive tape and the hook side of Velcro brand fastener) and three types of lures in the box (food - chicks, foreign spraints and cod liver oil). The 6-day test resulted in successful capturing otter hairs, and up to 52 hairs/24 hours were found glued on the adhesive tape that was fastened to the lid of the box. The set of sticks with Velcro strips was the less effective device with only five hairs collected in four days and spraints were the most effective lure.

The approaches above described revealed high potential for successful hair trapping but there is still the need to test non-invasive hair trapping methods in otters in the wild. They also addressed just two other species, the North American river otter and Eurasian otter, the two most know otter species.

The Neotropical otter (Lontra longicaudis Olfers, 1818) is considered "Near Threatened", both on a global scale (Rheingantz \& Trinca 2015) as well as in Brazil (Rodrigues et al. 2013). Robust ecological information is still lacking on population size, area of occupancy, genetic diversity, population connectivity, as well as on interactions with man (Barbieri et al. 2012, Rheingantz \& Trinca 2015), and exploring the application of non-invasive techniques for collecting hair samples is important.

The aim of this study was to develop a simple, cost-effective and rapid method to collect otter hair samples in a non-invasive way for future use in distribution studies, and in isotopic and molecular analysis. To our knowledge this is the first study of Neotropical otter hair capture method.

\section{Material and Methods}

The study was carried out in a $10 \mathrm{~km}$ stretch of the Paranapanema River, in Angatuba and Paranapanema municipalities, in São Paulo State, Brazil (Figure 1). This river stretch is located downstream of the Jurimirim hydroelectric station, with bordering landscape composed of riverine forests (with some degree of human disturbance including areas used by fishermen, small fishing and living houses, stretches of riparian deforestation) and agro-silvo-pastoral fields (e.g. Eucalyptus, corn and cotton plantations, cattle breeding pastures) (IBGE 2017). The area is characterized by a sub-tropical climate, with rainy summers and dry winters, and average temperatures of $22^{\circ} \mathrm{C}$ in the warmest month (March) and $17^{\circ} \mathrm{C}$ in the coldest (June) (CEPAGRI 2017).

This study site was chosen because regular presence of Neotropical otters was previously detected, based on fresh spraint (term used specifically for otter scats) daily observation and the identification of 


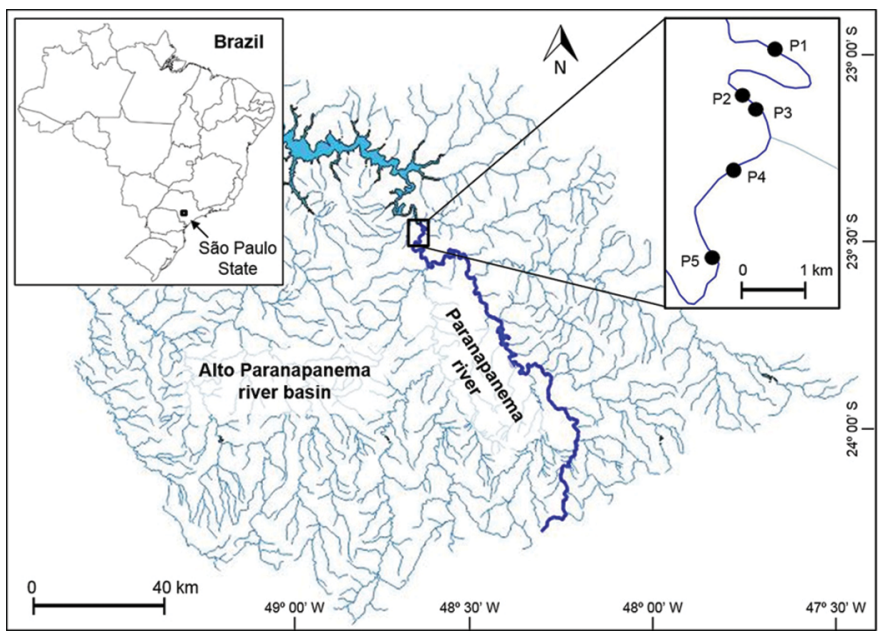

Figure 1. Study area location within Alto Paranapanema river basin, São Paulo State, Brazil. Black dots indicate sampling points (from P1 $-23^{\circ} 28^{\prime} 50^{\prime \prime} \mathrm{S}$, $48^{\circ} 37^{\prime} 12^{\prime \prime} \mathrm{W}$ to $\mathrm{P} 5$ - $23^{\circ} 30^{\prime} 57^{\prime \prime} \mathrm{S}, 48^{\circ} 37^{\prime} 55^{\prime \prime} \mathrm{W}$ )

several holts. Otters use holts and shelters even near disturbed areas (Santos \& Reis 2012). Nevertheless we selected sampling points outside the main human fishing areas and with adequate riparian cover. Hair traps consisted of rectangular $60 \mathrm{~cm}$ wooden sticks with double-sided adhesive tape (Axton 50mm light brown) wrapped around the part of the stick that was not buried. A variation was also tested using wax bands instead. When superficial tree roots were available these were preferred to sticks, as the first are more natural elements to otter habitat and involved less costs (Figure 2). Attaching the adhesive tape to roots was more difficult than the wax bands so the latter were more used in the roots. A total of 23 traps (17 sticks and six tree roots) were set on river banks, on otter trails and scent-marking sites. The number (ranging between two and seven) and type of trap that were placed at each sampling point depended on the area, structure, and substrate at the site. The low number of used roots reflects their low availability near the sampling points. The distance between the sticks varied between 40 to $60 \mathrm{~cm}$ depending on the site characteristics. Trap deployment was conducted on the $30^{\text {th }}$ May 2017.

To attract otter to the traps, we decided not to use traditional baits as fish, as otters do not readily take fish that they have not caught themselves (Kruuk 2006). Based on the knowledge that otters are territorial and mark intensively their territories and that spraint deposition is associated with territoriality and resource defence, and it is a powerful mean of intraspecific communication (Kruuk 1992), we baited each trap with fresh spraints from the same river but from other locations, the further possible from the sampled point to maximise the probability of being from a different individual. Spraints also have the advantage of decomposing slowly and not being eaten by other species nor stolen (Kuhn 2010).

Hair traps were checked after two and six nights. In the first checking, collected hairs were removed with sterile forceps and placed in individual plastic bags for future processing in the laboratory. Hair traps were removed at the end of day 6 since on the last night started to rain intensively and river water level started to increase, and would soon submerge some of the traps. During the sampling period there were no rain and water level remained stable. To avoid species misidentification, all sampled hairs were processed for observation of cuticular impressions and medullar pattern (Quadros \& MonteiroFilho 2006a, Martin et al. 2009) and identified to species level using mammal hair keys and guides (Quadros \& Monteiro-Filho 2006b, Kuhn \& Meyer 2010, Quadros \& Monteiro-Filho 2010). To check for differences between visits (two and six nights), we run a statistical test for "difference between two proportions" using STATISTICA software (version 13).

\section{Results}

Four of the five sampling points gave positive results. From the 23 traps, $10(43.7 \%)$ were successful in collecting otter hairs, mostly guard-hair (Figure 3, Table 1). Other otter hairs were also collected but as only guard-hairs are used for processing, we only considered these.

The sticks were much more efficient than the roots at capturing otter hair $(70.6 \%$ vs $0 \%)$ as well as adhesive tape when compared with wax $(71.4 \%$ vs $0 \%)$.

In the second visit to the traps (after six nights) some sticks were muddy and four sampling points were marked with spraints and the remaining two had claw marks, confirming that otters visited the sampling points during the study period. In the first visit (after two nights) just one trap had collected otter hairs (five in total, two of which

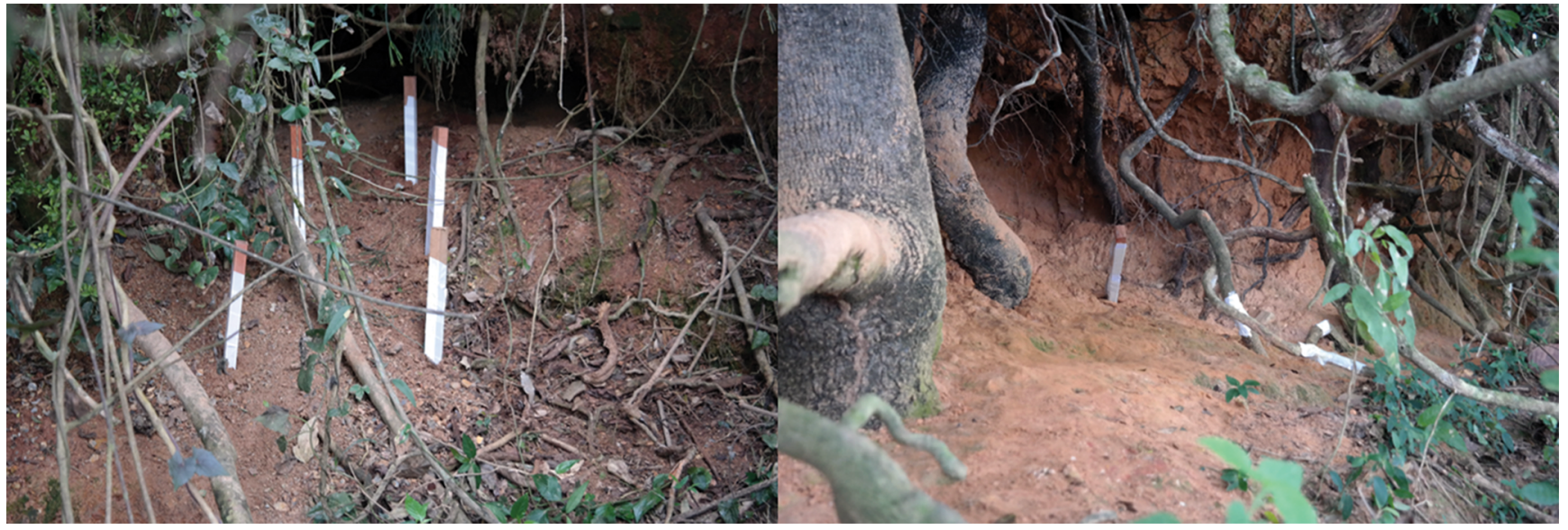

Figure 2. Sampling with sticks (left) and using roots (right) 


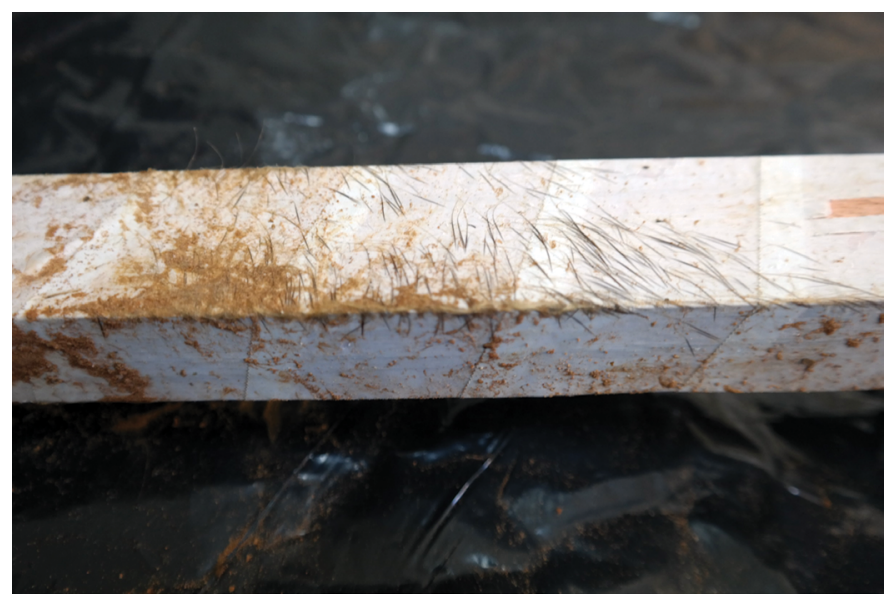

Figure 3. Otter hair trap (stick with adhesive tape) with dozens of otter hairs

Table 1. Number of Neotropical otter guard-hairs collected with adhesive tape and wax fastened to wooden sticks and tree roots in Paranapanema river (São Paulo State, Brazil)

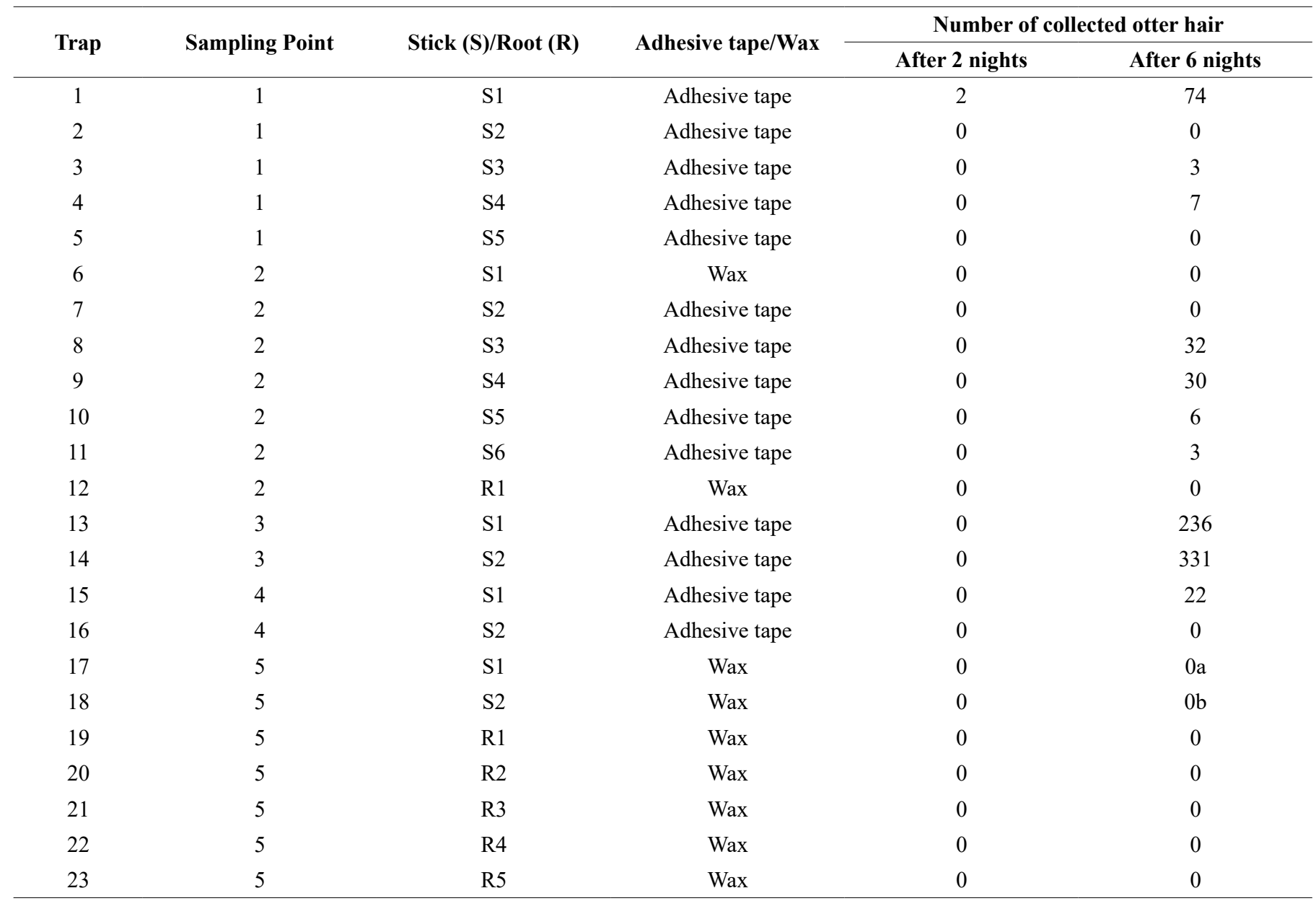

a 23 and ${ }^{\mathrm{b}} 19$ hairs of E. barbara were collected in this trap

guard-hairs). After six nights, many more hairs were collected in all sites $(p=0.0005$ - significant difference of proportions of sticks with adhesive tape between visits; $p=0.009$ - significant difference of sticks between visits). Some hairs were removed in the field with forceps and that proved to be more difficult with wax traps than with adhesive tape. Therefore, hair was removed from several sticks afterwards in the laboratory to prevent further manipulation in the field. Although field observation already pointed that, with the exception of two traps, no hair from other species was collected, this was additionally confirmed by cuticular impressions and medullar pattern observation. The non-otter hairs were of tayra (Eira barbara) and here the only hair trapped in wax. 
We found that tayra hair captured in wax is far more difficult to clean than otter hair from adhesive tape (both had 70\% - alcohol applied but wax needed a longer cleaning process). In addition, the former presented a more difficult cuticular identification probably due to both the more extensive clean-up process and to the initial damaging by the wax.

\section{Discussion}

The simplicity and efficiency of the method used suggest that it can be a cost-effective way for collecting otter hairs without the need for capturing individuals. The use of fresh spraints may induce the investigation by other otters and may be a key element for the method efficiency. Males may respond more intensively to fresh spraints than females and this may have influence on the type of study and objectives, so further tests including molecular analysis are needed.

Except for tayra, no hair from other non-otter species otter was collected. This is probably due to the specificity of the sampling points (steep margins near water in trails mostly possible to be accessed by semi-aquatic species rather than terrestrial species) and due to the use of fresh otter spraints as bait. Such specificity helps diminishing cross-contamination of DNA based on hair samples. The tayra is a typical forest species but also can be found in the vicinity of aquatic habitats (Nowak 1999) and can also use altered environments that provide resources (e.g. agriculture and plantations) (Presley 2000, Hunter \& Barrett 2011) as was the case of the surrounding environment of the sampling point were the hairs were collected.

The higher capture success in sticks when compared with roots was rather surprising as we expected that the latter, being more natural elements to the otter habitat, would capture more hair. A possible reason is the novelty in the otter environment investigated by the resident otters. Nevertheless, we must remind that the low availability of adequate roots near the sampling points led to an unbalanced number of the two types of traps used. Although both glue types captured hairs, only adhesive tape captured otter hairs. Additionally wax proved to be more inadequate as it damages the hair and decreases effectiveness of cuticular impressions and future molecular analysis. For this we recommend adhesive tapes.

This was a short-term study (six nights) and capture efficiency may vary if a longer capture campaign is conducted and with a higher number of traps. However, the minimum capture efficiency of our hair traps (one otter sample/2-6 trap-nights) was similar to the results of Depue \& Ben-David (2007) for river otter (one otter capture/2-228 trap-nights) and higher than live-capture rates for the same species (one otter capture/21-315 trap- nights; Melquist \& Hornocker 1983, Shirley et al. 1983, Serfass et al. 1996, Blundell et al. 1999, Belfiore 2008). The significant difference between the success of otter hair capture after two (low) and after six (high) days may be result of otters not using that specific part of the territory every night, so larger periods of sampling (several days/weeks) will improve capture efficiency.

The capture success in different study sites is presumably related to otter abundance (Depue \& Ben-David 2007). In this study, although otter numbers are not known, the daily presence of new otter spraints in most of the sampling points may suggest a high local otter density. Nevertheless it can also be a response of the same individual(s) to novel elements in its territory due to the short duration of the study (no time for habituation) and this needs further investigation. The high capture efficiency and success of hair traps was also likely a result of the high availability of otter holts and/or presence of otter signs of presence where the traps were deployed.

Our method can be used for the following tasks: a) assessment of local otter distribution; b) collecting otter hair samples for sex and individual identification (by molecular analysis); trophic ecology (by isotopic analyses); ecotoxicology (by contamination analysis) or behaviour ecology (by hormonal and stress levels analysis). Additionally, hair samples have proved to be a much more reliable (Anderson et al. 2006) and cost-effective (Johnson et al. 2013) source of DNA than spraints. Molecular and isotopic analysis success from the capture hairs in this study will be explored in future works but at the moment we can report that 11 otter hairs were selected for isotopic analyses and successfully used for establishing an isotopic signature and trophic niche for the Neotropical otter.

This method can be implemented in other regions for otter species with identified holts and/or tracks, in areas of usual otter marking. The degree of success is expected to be lower in areas where the habitat use is low, or where it is more difficult to identify otter holts (e.g. Eurasian otter in Mediterranean habitats where holts are mainly under vegetation), or in areas of low otter population density.

There are some possible method limitations that should be considered. One is loss of adhesive capabilities. These type of materials can lose their stickiness because of humidity but using stronger adhesive types may be more intrusive to animals. Consequently we advise not the use of stronger adhesive tape or wax but instead to check traps for loss of adherence and change tapes if and when necessary. In our case, during the six days of trapping, we had no need to change the adhesive tape or the wax but we advise checking for stickiness loss every three days especially in tropical (humid) environments. Also, the use of glue material in animal tissue may decrease effectiveness for ecotoxicological or molecular analysis. An alternative could be the use of velcro stripes but they seem to be less effective in capturing hairs, especially hairs with roots that are needed for molecular analysis. We must also take into consideration the possibility of water level variation in the river or stream were this method will be applied. Tropical environments (not only but especially) can be subjected to sudden and intense water level variations due to intense rain. If traps are subjected both to rain and especially to submersion, trap efficiency and hair sample analysis will decrease considerably. Consequently trapping campaigns should be conducted outside high rain and humidity periods if possible. Additionally, the use of these traps can affect or harm other animal such as insects. We did not found many insects captured in the traps, nevertheless, this is always a risk. Trap deployment should try to minimize non-targeted accidental catches.

More trapping campaigns should be implemented to further test the method's efficiency, with a higher number of trapping sites and a longer duration. Also, molecular analysis of the hairs collected should be performed to test individual identification, and test the DNA extraction efficiency in relation with hair cleaning processes. Although wooden sticks and tree roots can be used, sticks appear to be considerably more attractive for otter scent marking. Additionally, the use of other otter spraints as bait should be tested in relation with the distance from the sampling points as the response individuals might, by hypothesis, be stronger to neighbours than to distant animals. 


\section{Author Contributions}

Nuno M. Pedroso: Contribution to data collection; Contribution to data analysis and interpretation; Contribution to manuscript preparation; Contribution to critical revision, adding intellectual content.

Sofia V. Dias: Contribution to data collection; Contribution to data analysis and interpretation; Contribution to manuscript preparation; Contribution to critical revision, adding intellectual content.

Thais Rovere Diniz-Reis: Contribution to data collection; Contribution to data analysis and interpretation; Contribution to manuscript preparation; Contribution to critical revision, adding intellectual content.

Margarida Santos-Reis: Contribution to manuscript preparation; Contribution to critical revision, adding intellectual content.

Luciano Martins Verdade: Contribution to data collection; Contribution to data analysis and interpretation; Contribution to manuscript preparation; Contribution to critical revision, adding intellectual content.

\section{Conflicts of interest}

The authors declare that they have no conflict of interest related to the publication of this manuscript.

\section{References}

ANDERSON, H., MCCAFFERTY, D., SACCHERI, I. \& MCCLUSKI, A.E. 2006. Non-invasive genetic sampling of the Eurasian Otter (Lutra lutra) using hairs. Hystrix, It. J. Mamm 17(1):65-77.

BAKER, E.W. 1980. Hair-catchers aid in identifying mammalian predators of ground nesting birds. Wildl. Soc. Bull. 8257-259.

BARBIERI, F., MACHADO, R., ZAPPES, C.A. \& OLIVEIRA, L.R. de. 2012. Interactions between the Neotropical otter (Lontra longicaudis) and gillnet fishery in the southern Brazilian coast. Ocean Coast. Manag. 6316-23.

BELFIORE, N.M. 2008. Trapping and handling of North American river otters (Lontra canadensis) in a managed marsh. J. Zoo Wildl. Med. 39(1):13-20.

BEN-DAVID, M., BOWYER, R., DUFFY, L., ROBY, D. \& SCHELL, D. 1998. Social behavior and ecosystem processes: river otter latrines and nutrient dynamics of terrestrial vegetation. Ecology 79(7):2567-2571.

BLUNDELL, G.M., KERN, J.W., BOWYER, R.T. \& DUFFY, L.K. 1999. Capturing river otters: A comparison of Hancock and leg-hold traps. Wildl. Soc. Bull. 27:184-192.

CEPAGRI. 2017. Centro de Pesquisas Meteorológicas e Climáticas Aplicadas a Agricultura. (http://www.cepagri.unicamp.br/)

DEPUE, J.E. \& BEN-DAVID, M. 2007. Hair Sampling Techniques for River Otters. J. Wildl. Manage. 71(2):671-674.

FORAN, D.R., MINTA, S.C. \& HEINEMEYER, K.S. 1997. Of Hair DNABased species and analysis of hair for to identify individuals for Population Research and Monitoring. Wildl. Soc. Bull. 25(4):840-847.

HOBSON, K.A., SCHELL, D.M., RENOUF, D. \& NOSEWORTHY, E. 2000. Stable carbon and nitrogen isotopic fractionation between diet and tissue of captive red fox: implications for dietary reconstruction. Can. J. Zool. 78(5):848-852.

HUNTER, L. \& BARRETT, P. 2011. Carnivores of the world. Princeton University Press, New Jersey.

IBGE. 2017. Instituto Brasileiro de Geografia e Estatística. (http://downloads. ibge.gov.br/downloads_geociencias.htm\#)

IUCN. 2017. The IUCN Red List of Threatened Species. (http://www.iucnredlist. org)
JOHNSON, C.J., HODDER, D.P. \& CROWLEY, S. 2013. Assessing noninvasive hair and fecal sampling for monitoring the distribution and abundance of river otter. Ecol. Res. 28(5):881-892.

KOREN, L., MOKADY, O., KARASKOV, T., KLEIN, J., KOREN, G. \& GEFFEN, E. 2002. A novel method using hair for determining hormonal levels in wildlife. Anim. Behav. 63(2):403-406.

KRANZ, A. 1995. On the ecology of otters (Lutra lutra) in Central Europe. University of Agriculture, Vienna.

KRUUK, H. 1992. Scent marking by otters (Lutra lutra): signaling the use of resources. Behav. Ecol. 3(2):133-140.

KRUUK, H. 2006. Otters: ecology, behaviour, and conservation. Oxford University Press, Oxford.

KUHN, R.A. 2010. Note on Hair-Sampling Devices for Eurasian Otters. IUCN Otter Spec. Gr. Bull. 27(2):98-104.

KUHN, R.A. \& MEYER, W. 2010. Comparative hair structure in the Lutrinae (Carnivora: Mustelidae). Mammalia 74(3):291-303.

MACBETH, B.J., CATTET, M.R.L., STENHOUSE, G.B., GIBEAU, M.L. \& JANZ, D.M. 2010. Hair cortisol concentration as a noninvasive measure of long-term stress in free-ranging grizzly bears (Ursus arctos): considerations with implications for other wildlife. Can. J. Zool. 88(10):935-949.

MARTIN, P.S., GHELER-COSTA, C. \& VERDADE, L.M. 2009. Microestruturas de pêlos de pequenos mamíferos não-voadores: chave para identificação de espécies de agroecossistemas do estado de São Paulo, Brasil. Biota Neotrop. 9(1):233-241.

MELQUIST, W.E. \& HORNOCKER, M.G. 1983. Ecology of river otters in west-central Idaho. Wildl. Monogr. 83:3-60.

MITANI, N., MIHARA, S., ISHII, N. \& KOIKE, H. 2009. Clues to the cause of the Tsushima leopard cat (Prionailurus bengalensis euptilura) decline from isotopic measurements in three species of Carnivora. Ecol. Res. 24:897-908.

MITCHELL-JONES, A.J., JEFFERIES, D.J., TWELVES, J., GREEN, J. \& GREEN, R. 1984. A practical system of tracking otters using radio telemetry and 65- Zn. Lutra 27:71-74.

MONTERROSO, P., RICH, L.N., SERRONHA, A., FERRERAS, P. \& ALVES, P.C. 2014. Efficiency of hair snares and camera traps to survey mesocarnivore populations. Eur. J. Wildl. Res. 60(2):279-289.

MOWAT, G. \& STROBECK, C. 2000. Estimating population size of Grizzly Bears using hair capture, DNA profiling and mark-recapture analysis. J. Wildl. Manage. 64:183-193.

NEWSOME, S.D., TINKER, M.T., MONSON, D.H., OFTEDAL, O.T., RALLS, K., STAEDLER, M.M., FOGEL, M.L. \& ESTES, J.A. 2009. Using stable isotopes to investigate individual diet specialization in California sea otters (Enhydra lutris nereis). Ecology 90(4):961-974.

NOWAK. 1999. Walker's mammals of the world - Vol. I. JHU Press, Baltimore.

Ó NÉILL, L., WILSON, P., DE JONGH, A., DE JONG, T. \& ROCHFORD, J. 2008. Field techniques for handling, anaesthetising and fitting radiotransmitters to Eurasian otters (Lutra lutra). Eur. J. Wildl. Res. 54(4):681687.

PEREIRA, R., PEREIRA, M.L., RIBEIRO, R. \& GONÇALVES, F. 2006. Tissues and hair residues and histopathology in wild rats (Rattus rattus L.) and Algerian mice (Mus spretus Lataste) from an abandoned mine area (Southeast Portugal). Environ. Pollut. 139(3):561-575.

PRESLEY, S.J. 2000. Eira barbara. Mamm. Species 636(1):1.

QUADROS, J. \& MONTEIRO-FILHO, E.L.A. 2006a. Coleta e preparação de pêlos de mamíferos para identificação em microscopia óptica. Rev. Bras. Zool. 23(1):274-278.

QUADROS, J. \& MONTEIRO-FILHO, E.L.A. 2006b. Revisão conceitual, padrões microestruturais e proposta nomenclatória para os pêlos-guarda de mamíferos brasileiros. Rev. Bras. Zool. 23(1):279-292.

QUADROS, J. \& MONTEIRO-FILHO, E.L.A. 2010. Identificação de mamíferos de uma área de floresta Atlântica utilizando a microestrutura de pelos-guarda de predadores e presas. Arq. do Mus. Nac. Rio Janeiro 68(1-2):47-66. 
Hair sampling of otters

RHEINGANTZ, M.L. \& TRINCA, C.S. 2015. Lontra longicaudis. The IUCN Red List of Threatened Species 2015.

RODRIGUES, L.D.A., LEUCHTENBERGER, C., KASPER, C.B., CARVALHO-JUNIOR, O. \& SILVA, V.C.F. 2013. Avaliação do risco de extinção da Lontra neotropical Lontra longicaudis (Olfers, 1818) no Brasil. Biodiversidade Bras. 3(1):216-227.

SANTOS, L.B. \& REIS, N. 2012. Use of shelters and marking sites by Lontra longicaudis (Olfers, 1818) in lotic and semilotic environments. Biota Neotrop. 12(1):199-205.

SERFASS, T.L., BROOKS, R.P., SWIMLEY, T.J., RYMON, L.M. \& HAYDEN, A.H. 1996. Considerations for capturing, handling, and translocating river otters. Wildl. Soc. Bull. 24(1):25-31.
SHIRLEY, M.G., LINSCOMBE, R.G. \& SEVIN, L.R. 1983. A Live Trapping and Handling Technique for River Otter. Proc. Annu. Cont. Southeast. Assoc. Fish Wildl. Agencies 37:182-189.

SIKES, R.S. \& GANNON, W.L. 2011. Guidelines of the American Society of Mammalogists for the use of wild mammals in research. J. Mammal. 92(1):235-253.

VINE, S.J., CROWTHER, M.S., LAPIDGE, S.J., DICKMAN, C.R., MOONEY, N., PIGGOTT, M.P. \& ENGLISH, A. W. 2009. Comparison of methods to detect rare and cryptic species: A case study using the red fox (Vulpes vulpes). Wildl. Res. 36:436-446

WALTER, W.D., KURLE, C.M. \& HOPKINS, J.B. 2014. Applications of stable isotope analysis in mammalian ecology. Isotopes Environ. Health Stud. 50(3):287-290.

Received: 07/05/2018

Revised: 09/07/2018

Accepted: 13/08/2018

Published online: 21/09/2018

\section{ERRATUM}

In the article "Non-invasive hair sampling of Neotropical otters" with DOI code number http://dx.doi.org/10.1590/1676-0611-bn-2018-0579 published at Biota Neotropica 18(4): e20180579, the "Acknowledgements" section had not been included:

\section{Acknowledgements}

We would like to thank Juliana Quadros for the confirmation of hair identification. We acknowledge the logistic support of the "Estação Ecológica de Angatuba/Instituto Florestal/Secretaria de Estado do Meio Ambiente do Brasil”. NMP was supported by grant \#2014/08601-6, São Paulo Research Foundation (Fundação de Amparo à Pesquisa do Estado de São Paulo). LMV holds a Productivity Scholarship from Conselho Nacional de Desenvolvimento Científico e Tecnológico (CNPq, Proc. No. 312049/2015-3). 